\title{
ЦИФРОВАЯ ПОЧВЕННАЯ КАРТА ВОДОСБОРА РЕКИ СОКОЛОВКА (ТЕРРИТОРИЯ ВЕРХНЕУССУРИЙСКОГО СТАЦИОНАРА ФНЦ БИОРАЗНООБРАЗИЯ ДВО РАН)
}

\author{
Терешкина А.А. ${ }^{1}$, Пшеничникова Н.Ф. ${ }^{1}$, Бугаец А.Н. ${ }^{1}$, \\ Голодная О.М. ${ }^{2}$ Краснопеев С.М. ${ }^{1}$
}

\author{
${ }^{1}$ Тихоокеанский институт географии ДВО РАН, Владивосток \\ ${ }^{2}$ Федеральный научный центр биоразнообразия наземной биоты Восточной Азии \\ ДВО РАН, Владивосток \\ a.a.tereshkina@gmail.com
}

Аннотация. В работе приведены предварительные результаты создания цифровой почвенной карты для бассейна р. Правая Соколовка, территории Верхнеуссурийского стационара (ВУС) ФНЦ Биоразнообразия наземной биоты Восточной Азии ДВО РАН 1: 50 000. По природным условиям территория типична для среднегорного пояса, представляет собой характерный низко-среднегорный участок южного Сихотэ-Алиня. Климат района формируется под влиянием восточноазиатского муссона. В качестве топографической основы использована цифровая модель рельефа с пространственным разрешением 30 м (SRTM30), план лесонасаждений Верхнеуссурийского стационара, геологическая карта M 1: 200 000. Основными единицами карты являются почвенные подтипы. Номенклатура почв дана по региональной классификации Г. И. Иванова, выполнена адаптация к современной почвенной классификации Российской Федерации и проведена корреляция с номенклатурой почв Всемирной реферативной базой почвенных ресурсов (WRB). Каждый почвенный ареал включает данные по условиям формирования почв на уровне подтипа. Всего выделено десять подтипов. Показано, что в почвенно-растительном покрове четко выражена вертикальная зональность, представленная двумя почвенно-растительными поясами: горных буро-таежных и горно-подзолистых почв темнохвойных лесов и поясом горно-лесных бурых почв хвойно-широколиственных лесов. В поясе темнохвойных лесов в пределах высот 800-1000 м распространены горные ржавоземы грубогумусовые иллювиально-гумусированные, составляющие $23,8 \%$ от общей площади бассейна. В поясе хвойно-широколиственных лесов в основном распространены буроземы (70 \% от общей площади водосбора). Среди почв пойменных ландшафтов преобладают аллювиальные серогумусовые (дерновые) типичные. На основе информации по генетическим горизонтам создана база данных гидрофизических характеристик почв. По литературным источникам создана база данных физических характеристик почв (гранулометрический состав, глубина, вес, содержание гумуса) по генетическим горизонтам почвенных профилей (45 разрезов). С помощью алгоритмов обработки пространственных данных выполнен анализ численных характеристик морфометрии рельефа (средняя высота, уклон, площадь) почвенных ареалов.

Ключевые слова: водосбор, цифровая карта, ГИС, почвы, морфометрия рельефа. 


\title{
DIGITAL SOIL MAP OF SOKOLOVKA \\ RIVER CATCHMENT \\ (TERRITORY OF THE UPPER-RUSSIAN HOSPITAL OF FSC FOR BIODIVERSITY FEB RAS)
}

\author{
Tereshkina A.A ${ }^{1}$, Pshenichnikova N.F. ${ }^{1}$, Bugaets A.N. ${ }^{1}$, \\ Golodnaya O.M. ${ }^{2}$, Krasnopeev S.M. ${ }^{2}$
}

${ }^{1}$ Pacific Geographical Institute FEB RAS, Vladivostok

${ }^{2}$ Federal Scientific Center of the East Asia Terrestrial Biodiversity FEB RAS, Vladivostok

Annotation. The digital soil map (1: 50 000) of the Right Sokolovka River basin - the territory of the Upper Ussurian experimental station of the Centre of Biodiversity of the terrestrial biota of East Asia, FEB RAS. The main map units are soil subtypes. The soil nomenclature is given according to the regional classification, the adaptation to the modern soil classification of the Russian Federation was carried out and correlation with the soil nomenclature by the World Reference Base of Soil Resources was made. The calculation and preliminary analysis of the numerical characteristics of the morphometry of the topography of the soil areas has been performed.

Key words: digital soil map, soil, catchment, GIS, morphometry.

Представленная работа выполнена в рамках общего направления, цель которого - созданиt цифровой пространственной модели подстилающей поверхности водосбора, являющейся современной информационной и технологической основой исследований и моделирования гидрологических процессов [2]. Объектом исследования является почвенный покров бассейна р. Правая Соколовка территории Верхнеуссурийского стационара (ВУС) ФНЦ Биоразнообразия наземной биоты Восточной Азии ДВО РАН. Река Правая Соколовка является правым притоком четвертого порядка р. Уссури. Площадь ее водосбо-

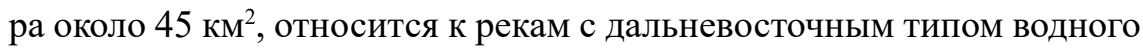
режима. Дождевые паводки, наблюдаемые в летне-осенний период, вносят основной вклад (в отдельные годы до $90 \%$ ) в общий годовой объем стока.

По природным условиям территория бассейна типична для среднегорного пояса, представляет собой характерный низко-среднегорный участок южного Сихотэ-Алиня. Климат района формируется под влиянием восточноазиатского муссона. Средняя годовая температура воздуха составляет $0.7^{\circ} \mathrm{C}$, с максимумом $37-38^{\circ} \mathrm{C}$ в июле-августе, и минимумом минус $43-45^{\circ} \mathrm{C}$ в январе. Среднегодовое количество осадков 780 мм, из них более 80 \% приходится на теплый период - с апре- 
ля по октябрь. Количество осадков может существенно варьировать от года к году, в летне-осенний период отклонения могут достигать 40-170 \% сезонной нормы. Суточный максимум осадков обусловлен влиянием тропических циклонов в августе-сентябре и может превышать 100 мм. Высота снежного покрова составляет 52-102 см, максимальная глубина промерзания достигает 53-125 см [16].

Перепад абсолютных высот находится в диапазоне от 444 м над уровнем моря в устье р. Правая Соколовка до 1108 м на вершине водораздела рек Соколовка и Павловка. Долина р. Правая Соколовка в нижней части составляет 200-500 м и вверх по течению сужается до 40-50 м [14, 22]. В геологическом отношении изучаемые объекты неоднородны. В бассейне кл. Медвежьего преобладают юрские метаморфические породы основного состава, а в бассейне кл. Елового - преимущественно породы меловых и триасовых вулканитов и субвулканитов кислого и среднего состава.

Основой для составления цифровой почвенной карты явились публикации по характеристике почвенного покрова бассейна р. Правая Соколовка сотрудников ФНЦ Биоразнообразия ДВО РАН, Дальневосточного научно-исследовательского института лесного хозяйства, Дальневосточного федерального университета, проводивших комплексные исследования лесных биогеоценозов на территории Верхнеуссурийского стационара [6-8, 12-13, 18-19]. В работе [19] приведена группировка горно-лесных почв бассейна р. Правая Соколовка (на уровнях тип, подтип, род, вид, разновидность) на основании которой составлена почвенная карта Верхнеуссурийского стационара в масштабе 1:25 000 на бумажном носителе.

Для построения цифровой почвенной карты (рис. 1) применялась методика, изложенная в работах $[1,5,21]$. В качестве топографической основы использована цифровая модель рельефа с пространственным разрешением 30 м (SRTM30, http://www.dgadv.com/srtm30/). Для уточнения местоположения почвенных разрезов, характеризующих выделенные почвенные ареалы и их связь с растительностью, использован план лесонасаждений Верхнеуссурийского стационара [17], составленный сотрудниками ДальНИИЛХ. Так же использована ранее оцифрованная в работе [5] геологическая карта М 1: 200000.

Основными единицами почвенной карты являются подтипы. Оцифровка ареалов проводилась с учетом указанных выше литературных источников и анализа современных данных дистанционного 
зондирования (ДД3). Легенда почвенной карты (табл. 1) построена на региональной классификации Г.И. Иванова [9-10], в основу которой положен подход разделения почв по характеру водообмена. Проведена корреляция региональной классификации почв с современной классификацией почв России [11] и номенклатурой почв Всемирной реферативной базы почвенных ресурсов (WRB) [15]. Каждый почвенный ареал включает данные по условиям формирования почв на уровне подтипа (табл. 2).

В почвенно-растительном покрове четко выражена вертикальная зональность. В пределах бассейна р. Правая Соколовка она представлена двумя почвенно-растительными поясами: поясом горных буро-таежных и горно-подзолистых почв темнохвойных лесов и поясом горно-лесных бурых почв хвойно-широколиственных лесов. Анализ выполнен последовательно для почв среднегорных, низкогорных и горно-пойменных ландшафтов. В поясе темнохвойных лесов в пределах высот 800-1000 м над уровнем моря распространены горные ржавоземы грубогумусовые иллювиально-гумусированные (по Г. И. Иванову [10] - буро-таежные иллювиально-гумусовые почвы), составляющие 23,8 \% от общей площади бассейна. Для них характерна глубокая гумусированность профиля и повышенная скелетность не только иллювиальной части профиля (обломки почвообразующих пород составляют 60-90 \% от объема почвенной массы), но и нередко верхней гумусированной части - до 60 \%. Высокое содержание обломочного материала обеспечивает свободный внутрипочвенный дренаж.

Ржавоземы грубогумусовые иллювиально-гумусированные представлены двумя подтипами (17,8 \% от общей площади): типичными и оподзоленными. Первые приурочены к верхним и средним частям склонов средней крутизны (до $13^{\circ}$ под папоротниковыми елово-пихтовым лесами. Вторые формируются на выположенных вершинах водоразделов под ельниками с участием мхов в напочвенном покрове. На выположенных верхушках водоразделов распространены горные буро-таежные иллювиально-гумусовые слаборазвитые (6 \% от общей площади бассейна) - литоземы серогумусовые иллювиально-гумусированные.

В поясе хвойно-широколиственных лесов широкое распространение (70 \% от общей площади бассейна) имеют буроземы (горно-лесные бурые почвы [10]). Их неоподзоленные подтипы (54 \% от общей 


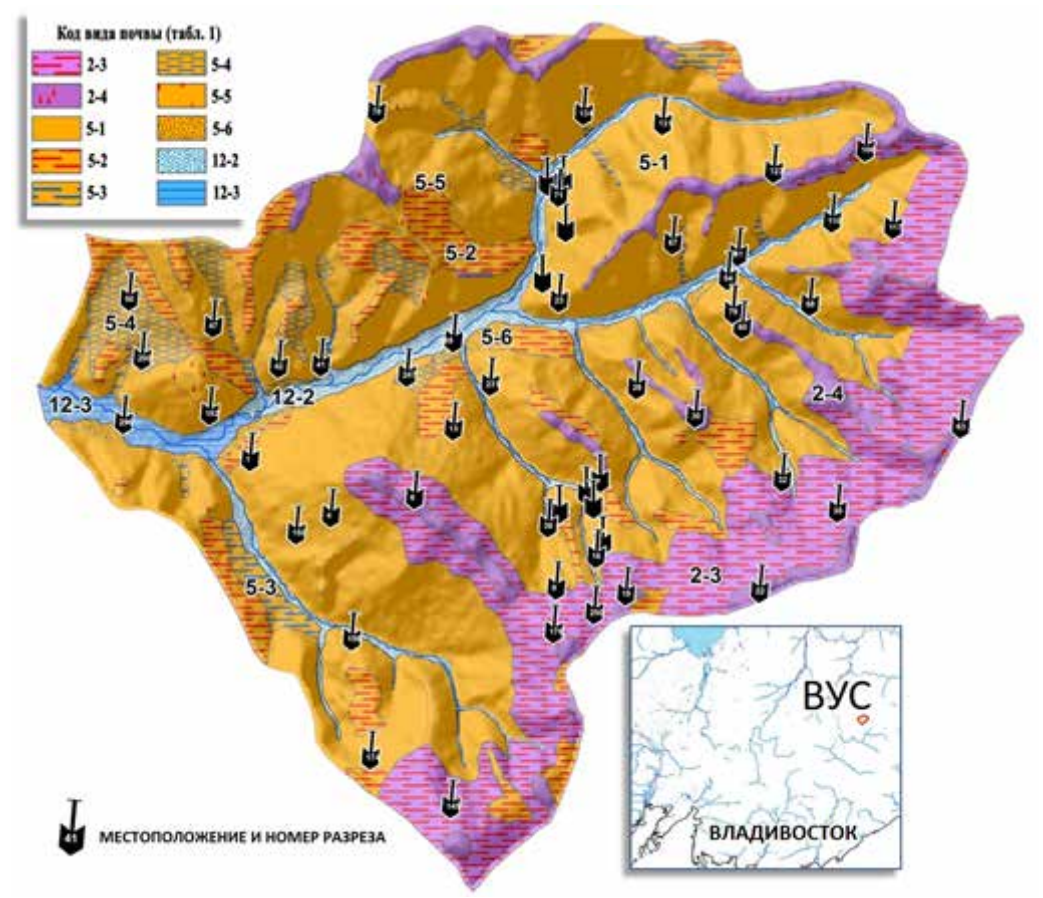

Рис. 1. Цифровая почвенная карта бассейна реки Правая Соколовка

площади бассейна) развиты на крутых склонах с более высокими абсолютными отметками (до высот 800 м). Они характеризуются быстрым водообменом. На высотах ниже 500-600 м над уровнем моря в условиях выположенного рельефа и сдержанного водообмена формируются буроземы оподзоленные, занимающие $9 \%$ от общей площади бассейна (горно-лесные бурые почвы [10]), а в местах с затрудненным водообменном - буроземы глееватые и поверхностно-глееватые (4,6% от общей площади бассейна). К верхним частям склонов приурочены литоземы серогумусовые ( $1,1 \%$ от общей площади бассейна).

Среди почв пойменных ландшафтов преобладают (5,8 \% - от общей площади бассейна) аллювиальные серогумусовые (дерновые) типичные которые развиты на надпойменной террасе на песчано-галечниковых отложениях и характеризуются быстрым водообменом. Эутрофные перегнойно-торфяные (торфянисто-перегнойно-глеевые [10]) почвы приурочены к заболоченным участкам поймы под ольхово-ясеневыми лесами, имеют ограниченное распространение (1,2 \% 


\section{Легенда цифровой почвенной карты бассейна р. Соколовка}

\begin{tabular}{|c|c|c|c|c|}
\hline 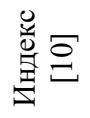 & $\begin{array}{c}\text { Название почвы по } \\
\text { региональной клас- } \\
\text { сификации [10] }\end{array}$ & $\begin{array}{c}\text { Название по совре- } \\
\text { менной классифика- } \\
\text { ции почв России [11] }\end{array}$ & $\begin{array}{c}\text { Англоязыч- } \\
\text { ное название } \\
\text { по [11] }\end{array}$ & WRB [15] \\
\hline \multicolumn{5}{|c|}{ Пояс горных буро-таежных и горно-подзолистых почв темнохвойных лесов [9] } \\
\hline \multicolumn{5}{|c|}{ Ландшафты быстрого водообмена } \\
\hline $2-3$ & $\begin{array}{l}\text { Горные буро-та- } \\
\text { ежные иллюви- } \\
\text { ально-гумусовые } \\
\text { неоподзоленные и } \\
\text { оподзоленные }\end{array}$ & $\begin{array}{l}\text { Ржавоземы грубогу- } \\
\text { мусовые иллювиаль- } \\
\text { но-гумусированные } \\
\text { типичные и оподзо- } \\
\text { ленные }\end{array}$ & $\begin{array}{l}\text { Typical and } \\
\text { podzolized } \\
\text { coarse-humus } \\
\text { humic illuvial } \\
\text { rzhavozems }\end{array}$ & $\begin{array}{l}\text { Dystric Cam- } \\
\text { bisols (Albic, } \\
\text { Humic) }\end{array}$ \\
\hline $2-4$ & $\begin{array}{l}\text { Горные буро-таеж- } \\
\text { ные иллювиально-гу- } \\
\text { мусовые слабораз- } \\
\text { витые }\end{array}$ & $\begin{array}{l}\text { Литоземы серогуму- } \\
\text { совые иллювиаль- } \\
\text { но-гумусированные }\end{array}$ & $\begin{array}{l}\text { Litozems hu- } \\
\text { mic illuvial }\end{array}$ & $\begin{array}{l}\text { Skeletic Dys- } \\
\text { tric Regosols } \\
\text { (Humic) }\end{array}$ \\
\hline \multicolumn{5}{|c|}{ Пояс горно-лесных бурых почв хвойно-широколиственных лесов } \\
\hline \multicolumn{5}{|c|}{ Ландшафты быстрого водообмена } \\
\hline $5-1$ & Горно-лесные бурые & Буроземы типичные & $\begin{array}{l}\text { Typical bu- } \\
\text { rozems }\end{array}$ & $\begin{array}{l}\text { Dystric Cam- } \\
\text { bisols }\end{array}$ \\
\hline $5-5$ & $\begin{array}{l}\text { Горно-лесные бурые } \\
\text { слаборазвитые }\end{array}$ & $\begin{array}{l}\text { Литоземы серогуму- } \\
\text { совые типичные }\end{array}$ & Litozems & $\begin{array}{l}\text { Skeletic Dys- } \\
\text { tric Cambisols }\end{array}$ \\
\hline \multicolumn{5}{|c|}{ Ландшафты сдержанного водообмена } \\
\hline $5-2$ & $\begin{array}{l}\begin{array}{l}\text { Горно-лесные бурые } \\
\text { оподзоленные }\end{array} \\
\end{array}$ & \begin{tabular}{|l|} 
Буроземы оподзо- \\
ленные
\end{tabular} & \begin{tabular}{|l|} 
Podzolized \\
burozems
\end{tabular} & $\begin{array}{l}\text { Dystric Cambi- } \\
\text { sols (Albic) }\end{array}$ \\
\hline $5-3$ & $\begin{array}{l}\text { Горно-лесные бурые } \\
\text { глеевые }\end{array}$ & Буроземы глееватые & $\begin{array}{l}\text { Gleyic bu- } \\
\text { rozems }\end{array}$ & $\begin{array}{l}\text { Gleyic Dystric } \\
\text { Cambisols }\end{array}$ \\
\hline $5-4$ & $\begin{array}{l}\text { Горно-лесные бурые } \\
\text { поверхностно-глее- } \\
\text { ватые }\end{array}$ & Буроземы глееватые & $\begin{array}{l}\text { Gleyic bu- } \\
\text { rozems }\end{array}$ & $\begin{array}{l}\text { Gleyic Stagnic } \\
\text { Dystric Cam- } \\
\text { bisols }\end{array}$ \\
\hline \multicolumn{5}{|c|}{ Почвы пойменных ландшафтов } \\
\hline $5-6$ & $\begin{array}{l}\text { Бурые лесные на } \\
\text { аллювиальных от- } \\
\text { ложениях (синоним: } \\
\text { бурые лесные оста- } \\
\text { точно-пойменные) }\end{array}$ & $\begin{array}{l}\text { Аллювиальные се- } \\
\text { рогумусовые (дерно- } \\
\text { вые) типичные }\end{array}$ & $\begin{array}{l}\text { Typical } \\
\text { grey-humus } \\
\text { (sod) alluvial } \\
\text { soils }\end{array}$ & $\begin{array}{l}\text { Fluvic Dystric } \\
\text { Cambisols }\end{array}$ \\
\hline $12-2$ & $\begin{array}{l}\text { Остаточно-поймен- } \\
\text { ные (синоним: дер- } \\
\text { ново-аллювиальные) }\end{array}$ & $\begin{array}{l}\text { Аллювиальные се- } \\
\text { рогумусовые (дерно- } \\
\text { вые) типичные }\end{array}$ & $\begin{array}{l}\text { Typical } \\
\text { grey-humus } \\
\text { (sod) alluvial } \\
\text { soils } \\
\end{array}$ & $\begin{array}{l}\text { Distric Fluvi- } \\
\text { sols }\end{array}$ \\
\hline $12-3$ & $\begin{array}{l}\text { Торфянисто-перег- } \\
\text { нойно-глеевые }\end{array}$ & $\begin{array}{l}\text { Эутрофные перег- } \\
\text { нойно-торфяные }\end{array}$ & \begin{tabular}{|l} 
Eutrophic \\
peat-humus \\
soils \\
\end{tabular} & $\begin{array}{l}\text { Sapric Dys- } \\
\text { tric Histosols } \\
\text { (Gleyic) } \\
\end{array}$ \\
\hline
\end{tabular}


от общей площади бассейна) и характеризуются затрудненным и застойным водообменом.

Таблица 2

Почвы, элементы рельефа, почвообразующие породы и растительность

\begin{tabular}{|c|c|c|c|c|}
\hline $\begin{array}{c}\text { Индекс } \\
\text { [10] }\end{array}$ & Элемент рельефа & $\begin{array}{c}\text { Почвообразую- } \\
\text { щие породы }\end{array}$ & Растительность & $\begin{array}{c}\text { площадь, } \\
\text { \% }\end{array}$ \\
\hline $2-3$ & $\begin{array}{l}\text { Вершины водораз- } \\
\text { делов, верхние и } \\
\text { средние части крутых } \\
\text { склонов }\end{array}$ & $\begin{array}{l}\text { Элювиальные и } \\
\text { элюво-делюви- } \\
\text { альные щебни- } \\
\text { стые отложения }\end{array}$ & $\begin{array}{l}\text { Елово-пихтовые } \\
\text { леса с кедром, ело- } \\
\text { во-пихтовые папо- } \\
\text { ротниковые леса }\end{array}$ & 17,9 \\
\hline $2-4$ & $\begin{array}{l}\text { Выположенные водо- } \\
\text { разделы, верхние ча- } \\
\text { сти крутых склонов }\end{array}$ & $\begin{array}{l}\text { Делювиальные } \\
\text { щебнистые отло- } \\
\text { жения }\end{array}$ & $\begin{array}{l}\text { Елово-пихтовые } \\
\text { леса }\end{array}$ & 6,0 \\
\hline $5-1$ & $\begin{array}{l}\text { Средние и верхние } \\
\text { части склонов }\end{array}$ & $\begin{array}{l}\text { Делювиальные } \\
\text { отложения }\end{array}$ & $\begin{array}{l}\text { Кедрово-широко- } \\
\text { лиственные леса с } \\
\text { елью }\end{array}$ & 54 \\
\hline $5-5$ & $\begin{array}{l}\text { Узкие выположенные } \\
\text { водоразделы }\end{array}$ & $\begin{array}{l}\text { Элювиально-де- } \\
\text { лювиальные от- } \\
\text { ложения }\end{array}$ & $\begin{array}{l}\text { Елово-пихтовые } \\
\text { леса }\end{array}$ & 1,2 \\
\hline $5-2$ & $\begin{array}{l}\text { Выположенные сред- } \\
\text { ние части склонов }\end{array}$ & $\begin{array}{l}\text { Элювиально-де- } \\
\text { лювиальные от- } \\
\text { ложения }\end{array}$ & $\begin{array}{l}\text { Кедрово-широко- } \\
\text { лиственные леса }\end{array}$ & 9,0 \\
\hline $5-3$ & $\begin{array}{l}\text { Нижние части поло- } \\
\text { гих и очень пологих } \\
\text { склонов }\end{array}$ & $\begin{array}{l}\text { Делювиальные } \\
\text { отложения }\end{array}$ & $\begin{array}{l}\text { Кедрово-широко- } \\
\text { лиственные леса }\end{array}$ & 1,7 \\
\hline $5-4$ & $\begin{array}{l}\text { Нижние и средние ча- } \\
\text { сти пологих и очень } \\
\text { пологих склонов }\end{array}$ & $\begin{array}{l}\text { Делювиальные } \\
\text { отложения }\end{array}$ & $\begin{array}{l}\text { Кедрово-широко- } \\
\text { лиственные леса } \\
\text { (вырубки) }\end{array}$ & 3,0 \\
\hline $5-6$ & $\begin{array}{l}\text { Надпойменные тер- } \\
\text { расы }\end{array}$ & $\begin{array}{l}\text { Песчано-галечни- } \\
\text { ковые отложения }\end{array}$ & $\begin{array}{l}\text { Долинный кедров- } \\
\text { ник (вырубки) }\end{array}$ & 0,9 \\
\hline $12-2$ & Пойменные террасы & $\begin{array}{l}\text { Аллювий песча- } \\
\text { но-галечниковый }\end{array}$ & $\begin{array}{l}\text { Долинные кедро- } \\
\text { во-широколиствен- } \\
\text { ные леса }\end{array}$ & 5,0 \\
\hline $12-3$ & $\begin{array}{l}\text { Заболоченные участки } \\
\text { поймы }\end{array}$ & $\begin{array}{l}\text { Аллювий средне- } \\
\text { суглинистый }\end{array}$ & $\begin{array}{l}\text { Заболоченные оль- } \\
\text { хово-ясеневые леса }\end{array}$ & 1,3 \\
\hline
\end{tabular}

На заключительном этапе с помощью алгоритмов обработки цифровых моделей рельефа и оверлейных функций геоинформационных систем выполнен расчет основных численных характеристик морфометрических параметров рельефа (высоты и крутизны в пределах ареалов основных подтипов почв исследуемой территории). Полученные данные были сопоставлены с основными характеристиками почвен- 
ного покрова для поиска устойчивых сочетаний, объясняющих взаимное расположение почвенных ареалов в пространстве.

В качестве краткого резюме отметим, что перспективы развития почвенного картографирования, применение цифровых почвенных карт и баз данных, содержащих информацию о физических и гидрологических характеристиках почв, в качестве современной информационной и технологической основы исследований и моделирования, крайне востребованы в регионе [2-4, 20-23]. Для создания карты были использованы современные данные ДДЗ, ГИС-технологии и методики верификации результатов, в том числе представленные результаты были использованы для моделирования гидрологического режима и оценки компонентов водного цикла $[14,22]$. Представленные результаты работы являются предварительными, дальнейшие исследований будут расширены с помощью применения методов геостатистики и математического моделирования.

\section{Литература}

1. Бугаец А.Н. Пшеничникова Н.Ф., Терешкина А.А., Краснопеев С.М., Гарцман Б.И. Анализ пространственной дифференциации почвенного покрова юга Приморья на примере бассейна р. Комаровка // Почвоведение. 2015. № 3. С. 268-276.

2. Бугаец А.Н., Гарцман Б.И., Краснопеев С.М. Создание современной информационной и технологической основы исследований и моделирования гидрологических процессов // Материалы XIV совещания географов Сибири и Дальнего Востока. Владивосток: Дальнаука, 2011. С. 570-572.

3. Бугаец А.Н., Гарцман Б.И., Терешкина А.А., Гончуков Л.В., Бугаец Н.Д., Сидоренко Н.Ю., Пшеничникова Н.Ф., Краснопеев С.М. Опыт применения модели SWAT для изучения гидрологического режима малого речного бассейна (река Комаровка, Приморский край) // Метеорология и гидрология. 2018. № 5. С. 68-79.

4. Бугаец А.Н., Мотовилов Ю.Г., Гарцман Б.И., Калугин А.С., Гончуков Л.В., Соколов О.В., Фролова Н.Л., Зотов Л.В., Григорьев В.Ю., Соколов А.А., Краснопеев С.М., Шамов В.В., Ознобихин В.И. Современные возможности и перспективы прогнозирования гидрологического режима бассейна озера Ханка с помощью физико-математического моделирования // Трансграничное озеро Ханка: причины повышения уровня воды и экологические угрозы. Владивосток: Дальнаука, 2016. С. 108-114.

5. Бугаец А.Н., Пшеничникова Н.Ф., Терешкина А.А., Краснопеев С.М., Гарцман Б.И., Голодная О.М., Ознобихин В.И. Цифровая почвенная карта бассейна р. Уссури // Почвоведение. 2017. № 8. С. 936-945.

6. Гавренков Г.И. Механический состав почв Верхнеуссурийского стационара // Комплексные исследования лесных биогеоценозов. Владивосток: ДВНЦ АН СССР, 1980. C. 55-73.

7. Гавренков Г.И., Костенкова А. Ф., Сапожников А.П. Сравнительная характеристика органического вещества почв ельников и кедровников Верхнеуссурийского 
стационара // Экология и продуктивность лесных биоценозов. Владивосток, 1979. C. $36-45$.

8. Гавренков Г.И. К характеристике почв Верхнеуссурийского стационара // Стационарные исследования в лесах Сихотэ-Алиня. Владивосток, 1977. С. 18-25.

9. Иванов Г.И. Почвенная карта Приморского края. Масштаб 1:500000. Хабаровск: ГУГК № 2, 1983. 2, 4, 8 листы.

10. Иванов Г.И. Почвообразование не юге Дальнего Востока. М.: Наука, 1976. $200 \mathrm{c}$.

11. Классификация и диагностика почв России. Смоленск: Ойкумена, 2004. 342 c.

12. Комплексные исследования лесных биогеоценозов. Владивосток, 1980. $140 \mathrm{c}$.

13. Костенкова А.Ф. Типы биологического круговорота веществ в горных биогеоценозах южного Приморья // Биогеоценологические исследования в лесах южного Сихотэ-Алиня. Владивосток: ДВНЦ АН СССР, 1982. С. 29-38.

14. Лупаков С.Ю., Гарцман Б.И., Бугаец А.Н., Гончуков Л.В., Шамов В.В., Пшеничникова Н.Ф., Терешкина А.А., Кожевникова Н.К., Краснопеев С.М. Моделирование гидрологического режима малых водосборов на основе данных полевых наблюдений (река правая Соколовка, верховья Уссури) // Геосистемы Северо-Восточной Азии: особенности их пространственно-временных структур, районирование территории и акватории. Владивосток: ФГБУН ТИГ ДВО РАН, 2019. С. 258-263.

15. Мировая реферативная база почвенных ресурсов 2014. Международная система почвенной классификации для диагностики почв и создания легенд почвенных карт. Исправленная и дополненная версия 2015. ФАО и Московский государственный университет имени М.В. Ломоносова, 2017. 216 с.

16. Научно-прикладной справочник по климату СССР. Многолетние данные. Приморский край. Л.: Гидрометеоиздат, 1988. Сер. 3. Вып. 26. 416 с.

17. План лесонасаждений Верхнеуссурийского биогеоценотического стационара БПИ ДВНЦ АН СССР. ДальНИИЛХ Приморского края, масштаб 1:10 000, 1975. 1 лист.

18. Сапожников А.П. Селиванова Г.А, Ильина Т.М., Дюкарев В.Н., Бутовец Г.А., Гладких Г.А., Гавренков Г.И., Жильцов А.С. Почвообразование и особенности биологического круговорота веществ в горных лесах Южного Сихотэ-Алиня (на примере Верхнеуссурийского стационара). Хабаровск: ДальНИИЛХ, 1993. 270 с.

19. Селиванова Г.А. Некоторые черты динамики почвенных процессов в лесных биогеоценозах Верхнеуссурийского стационара // Комплексные исследования лесных биогеоценозов. Владивосток, 1980. С. 79-90.

20. Терешкина А.А., Бугаец А.Н., Пшеничникова Н.Ф., Голодная О.М., Ознобихин В.И. Опыт создания базы данных гидрофизических характеристик почвенного покрова и моделирования гидрологического цикла малого речного бассейна на примере реки Комаровка // Материалы конференции «Роль почв в биосфере и жизни человека». М.: МГУ, 2015. С. 117-119.

21. Терешкина А.А., Пшеничникова Н.Ф., Бугаец А.Н., Гарцман Б.И., Краснопеев С.М. Опыт создания цифровой пространственной модели подстилающей поверхности водосбора // Устойчивое природопользование в прибрежно-морских зонах. Материалы конференции. Владивосток: Дальнаука, 2013. С. 160-165. 
22. Bugaets A.N., Gartsman B.I., Lupakov S.Yu., Shamov V.V., Gonchukov L.V., Pshenichnikova N.F., Tereshkina A.A. Hydrological regime modeling of the small testbed catchments based on the field observations (a case study of the Pravaya Sokolovka River, the upper Ussuri Rivers basin) // Water Resources. 2019. Vol. 46, Suppl. 2. P. S8-S16.

23. Motovilov Yu.G., Bugaets A.N., Gartsman B.I., Gonchukov L.V., Kalugin A.S., Moreido V.M., Suchilina Z.A., Fingert E.A. Assessing the sensitivity of a model of runoff formation in the Ussuri river basin // Water Resources. 2018. Vol. 45. № S1. P. S128-S134.

\section{References}

1. Bugaets A.N., Tereshkina A.A., Gartsman B.I., Pshenichnikova N.F., Krasnopeev S.M. Analysis of the spatial differentiation of the soil cover in the south of the far east of Russia by the example of the Komarovka River basin. Eurasian Soil Science, 2015, vol. 48, no. 3, pp. 231-239.

2. Bugaets A.N., Gartsman B.I., Krasnopeev S.M. [Towards a modern information and technological basis for research and modeling of hydrological processes]. Materialy XIV soveshchaniya geografov Sibiri i Dal'nego Vostoka [Proceedings of the XIV meeting of geographers of Siberia and the Far East]. Vladivostok, Dalnauka Publ., 2011, pp. 570572.

3. Bugaets A.N., Gartsman B.I., Tereshkina A.A., Gonchukov L.V., Bugaets N.D., Sidorenko N.Yu., Pshenichnikova N.F., Krasnopeev S.M. Using the SWAT model for studying the hydrological regime of a small river basin (the Komarovka River, Primorsky Krai). Russian Meteorology and Hydrology, 2018, vol. 43, no. 5, pp. 323-331.

4. Bugaets A.N. et.al. [Opportunities and prospects for predicting the hydrological regime of the Khanka Lake basin using physico-mathematical modeling]. Transgranichnoe ozero Hanka: prichiny povysheniya urovnya vody i ekologicheskie ugrozy [Transboundary Lake Khanka: reasons for increasing the water level and ecological threats]. Vladivostok, Dalnauka Publ., 2016, pp. 108-114.

5. Bugaets A.N., Pschenichnikova N.F., Tereshkina A.A., Krasnopeev S.M., Gartsman B.I., Golodnaya O.M., Oznobikhin V.I. Digital soil map of the Ussuri River basin. Eurasian Soil Science, 2017, vol. 50, no. 8, pp. 907-916.

6. Gavrenkov G.I. [Granulometric texture of the soils of the Upper Ussuri station]. Kompleksnye issledovaniya lesnyh biogeocenozov [Integrated studies of forest biogeocenoses]. Vladivostok, 1980, pp. 55-73.

7. Gavrenkov G.I., Kostenkova A.F., Sapozhnikov A.P. [Comparative characteristics of the organic matter of the spruce forests and cedar forests of the Verkhne-Ussuriiski station]. Ekologiya i produktivnost' lesnyh biocenozov [Ecology and productivity of forest biocenoses]. Vladivostok, 1979, pp. 36-45.

8. Gavrenkov G.I. [On soil characterization of the Upper Ussuri experimental station]. Stacionarnye issledovaniya v lesah Sihote-Alinya [Stationary research in the forests of Sikhote-Alin]. Vladivostok, 1977, pp. 18-25.

9. Ivanov G.I. Pochvennaya karta Primorskogo kraya [Soil map of Primorsky Krai]. Scale 1: 500000. Khabarovsk: GUGK No. 2, 1983.

10. Ivanov G.I. Pochvoobrazovanie ne yuge Dal'nego Vostoka [Soil formation in the south of the Far East]. Moscow, Nauka Publ., 1976. 200 p.

11. Klassifikaciya i diagnostika pochv Rossii [Classification and diagnostics of Russian soils]. Smolensk, Oikumena Publ., 2004. 342 p. 
12. Kompleksnye issledovaniya lesnyh biogeocenozov [Comprehensive studies of forest biogeocenoses]. Vladivostok, 1980. 140 p.

13. Kostenkova A.F. [Types of the biological cycle of substances in mountain biogeocenoses of southern Primorye]. Biogeocenologicheskie issledovaniya v lesah yuzhnogo Sihote-Alinya [Biogeocenological studies in the forests of southern Sikhote-Alin]. Vladivostok, 1982, pp. 29-38.

14. Lupakov S.Yu., et.al. [Modeling the hydrological regime of small catchments based on field observations (right Sokolovka river, Ussuri upper)]. Geosistemy Severo-Vostochnoj Azii: osobennosti ih prostranstvenno-vremennyh struktur, rajonirovanie territorii $i$ akvatorii [Geosystems of North-East Asia: features of their spatio-temporal structures, zoning of the territory and water area]. Vladivostok, 2019, pp. 258-263.

15. IUSS Working Group WRB, 2015. World Reference Base for Soil Resources 2014, update 2015. International Soil Classification System for Naming Soils and Creating Legends for Soil Maps, World Soil Resources Reports, No. 106. FAO, Rome.

16. Nauchno-prikladnoj spravochnik po klimatu SSSR. Mnogoletnie dannye. Primorskij kraj. [Climate of the USSR. Long-term data. Vol. 26. Primorsky Krai]. Leningrad, Gidrometeoizdat Publ., 1988. 416 p.

17. Plan lesonasazhdenij Verhneussurijskogo biogeocenoticheskogo stacionara BPI $D V N C$ AN SSSR [Forest inventory map of the Verkhneussuriiskogo biogeocenotic experimental station] 1:10 000, 1975.

18. Sapozhnikov A.P. Selivanova G.A, Il'ina T.M., Dyukarev V.N., Butovets G.A., Gladkikh G.A.,Gavrenkov G.I., Zhil'tsov A.S. Pochvoobrazovanie i osobennosti biologicheskogo krugovorota veshchestv $v$ gornyh lesah Yuzhnogo Sihote-Alinya (na primere Verhneussurijskogo stacionara) [Soil formation and features of the biological cycle of substances in the mountain forests of the South Sikhote-Alin (on the example of the Verkhneussuriysky experimental station)]. Khabarovsk, 1993. 270 p.

19. Selivanova G.A. [Some features of the dynamics of soil processes in forest biogeocenoses of the Verkhneussursky experimental station]. Kompleksnye issledovaniya lesnyh biogeocenozov [Integrated studies of forest biogeocenoses]. Vladivostok, 1980, pp. 79-90.

20. Tereshkina A.A., Bugaets A.N., Pshenichnikova N.F., Golodnaya O.M., Oznobikhin V.I. [The experience of creating a database of hydrophysical characteristics of the soil and modeling the hydrological cycle of a small river basin on the example of the Komarovka River]. Materialy konferencii «Rol'pochv v biosfere i zhizni cheloveka» [Proceeding of conference "The role of soils in the biosphere and human life"]. Moscow, Moscow State Univ. Publ., 2015, pp. 117-119.

21. Tereshkina A.A, Pshenichnikova N.F., Bugaets A.N., Gartsman B.I., Krasnopeev S.M. [The experience of creating a digital spatial model of the underlying surface of the catchment]. Materialy konferencii «Ustojchivoe prirodopol'zovanie v pribrezhno-morskih zonah» [Proceeding of conference "Sustainable use of natural resources in coastal zones"]. Vladivostok, Dalnauka Publ., 2013, pp. 160-165.

22. Bugaets A.N., Gartsman B.I., Lupakov S.Yu., Shamov V.V., Gonchukov L.V., Pshenichnikova N.F., Tereshkina A.A. Hydrological regime modeling of the small testbed catchments based on the field observations (a case study of the Pravaya Sokolovka River, the upper Ussuri Rivers basin). Water Resources, 2019, vol. 46, suppl. 2, pp. S8-S16.

23. Motovilov Yu.G., Bugaets A.N., Gartsman B.I., Gonchukov L.V., Kalugin A.S., Moreido V.M., Suchilina Z.A., Fingert E.A. Assessing the sensitivity of a model of runoff formation in the Ussuri river basin. Water Resources, 2018, vol. 45, no. S1, pp. S128-S134. 